\title{
Oral Health Status in Adult Population in Chile (Decayed, Missing, Filled and Permanent Tooth): Clinical Observation at National Level
}

\author{
Verónica Vargas-Sanhueza1, Claudia Krause Muñoz², Víctor Patricio Díaz-Narváez ${ }^{3}$, \\ Juan Fonseca Molina ${ }^{4}$ \\ ${ }^{1}$ Faculty of Dentistry, Universidad Finis Terrae, Providencia, Región Metropolitana, Chile \\ ${ }^{2}$ DDS, Academic and Healthcare Office, Macul Clinical Campus, Faculty of Dentistry, Finis Terrae University, \\ Providencia, Región Metropolitana, Chile \\ ${ }^{3}$ Faculty of Dentistry, Universidad San Sebastián, Santiago, Región Metropolitana, Chile \\ ${ }^{4}$ DDS, Faculty of Dentistry, Universidad San Sebastián, Concepción, Chile \\ Email: *victor.diaz@uss.cl
}

Received 26 November 2015; accepted 26 December 2015; published 29 December 2015

Copyright (C) 2015 by authors and Scientific Research Publishing Inc.

This work is licensed under the Creative Commons Attribution International License (CC BY).

http://creativecommons.org/licenses/by/4.0/

(c) (i) Open Access

\begin{abstract}
Objectives: The aim of this study was to establish the differences in the oral health status of adult population between women and men by the clinical status of the permanent first molar. Methods: The data were obtained in a non-random sample of 132,174 patients from a large cohort who were under dental treatment nationwide in Chile during 2011. Results: The results show a greater frequency of "filled and not decayed" (45.6\%), "decayed" (18.8\%) and followed by "missing by decay" (15.4\%). Moreover, an association is established between the "filled and decayed" condition to the female gender and the condition "decayed" and "missing by decay" to the male gender (Significance level $\alpha \leq 0.05$ ). Conclusions: This study concluded that there was a dependent association between gender and the oral health status of permanent first molars in adult patients.
\end{abstract}

Keywords

Chile

\footnotetext{
*Corresponding author.

How to cite this paper: Vargas-Sanhueza, V., Muñoz, C.K., Díaz-Narváez, V.P. and Molina, J.F. (2015) Oral Health Status in Adult Population in Chile (Decayed, Missing, Filled and Permanent Tooth): Clinical Observation at National Level. Health, 7, 1757-1762. http://dx.doi.org/10.4236/health.2015.712191
} 


\section{Introduction}

The study of damage related to dental caries in adults at a global level is scarce, and in recent years is an epidemiological concern because it drives us to the needs of dental treatment. There are a few studies that account for the oral health status of Chilean adults [1]-[3] and according to the Health Ministry of the Government of Chile, the population older than 20 years old are the most affected in the perception of their quality of life [4]. National studies carried out by the Chilean Ministry of Health, and by the National Health Survey in 2003 [5] involved 3308 people over 17 years old, based on the presence of decay teeth, remaining teeth, and dental prosthesis use, this examination was carried out at home by a calibrated nurse. The studies are mainly based on the use of ranges of damage by the index: D:decay, F: filled, M: missing, T: permanent tooth (DFMT), which has been used for 70 years, originally aimed to children, but today efforts involve the older adult population [6]. In 2007, a study of 12 years old population, supported it by the government of Chile, showed an increased prevalence of caries-free teeth in men and greater DMFT index on women [3]. Recent studies on oral health status in adults made in South Vietnam [7] $(\mathrm{n}=2965)$, Bulgaria [8] $(\mathrm{n}=2531)$, China [9] $(\mathrm{n}=1588)$ and Tanzania [10] $(\mathrm{n}=$ 5532), conclude that the molar teeth have an increased risk of carious lesion or being missing than the anterior teeth and premolars, but the association of gender with DFMT index and its components is variable. For studies conducted in South Vietnam [7] and China [9], females had increased risk of caries lesions, greater chance for sealed and lower risk to being missing, in Bulgaria females had greater risk for missing teeth and filled teeth. The study in South Australia [11] ( $\mathrm{n}=709)$ found that males had fewer risk for missing teeth, unlike Brazil study [12] $(n=1159)$ where males had a greater risk for missing teeth and increased risk of carious lesions. The benefits in the oral health are directly reflected in better chewing ability of the adult population when the molars are presented [13]. In view of the above, the objective of this study was to establish the association of oral health status by gender in adult patients undergoing dental treatment in Chile through the clinical examination of the permanent first molars.

\section{Material and Method}

This study is not experimental, exploratory and transversal [14]. It was approved by the Research Ethics Committee of the Universidad Finis Terrae before starting. The encoded data, impossible to identify participants, was obtained from the records contained in electronic medical record and correspond to the total number of cases admitted into private oral health centers from a nationwide network in 2011. The demographic characteristics of the study population have been described in a previous paper [15]. The study population was 648, 235 cases, the sample ( $\mathrm{n}=$ $132,174)$ was not randomized. From the observed data of the complete medical records of adults patients, aged 20-64, the conditions of the permanent first molar was studied (3P, 14P, 19P and 30P: according to FDI nomenclature (World Dental Federation), were estimated frequency, and cumulative percentage of each conditions relating to the dental status of the permanent first molars, these being: decay, filled and decay, white spot, sealant and varnish, filled and not decay, crowned, missing by caries, missing by other reason, unerupted and unexamined. Subsequently, there was calculated the association between the condition of each molar with patient gender by $\chi^{2}$ test (chi square test) in the form of contingency tables. The level of significance in all cases was $\alpha \leq 0.05$.

\section{Results}

Table 1 shows the results of the frequencies, percentages and cumulative percent of dental conditions of teeth 3P (upper right first permanent molar), the highest frequency observed is "filled and not decay" (45.6\%), followed by "decay" (18.8\%), "missing by caries" (15.4\%), "filled and decay" (6.3\%) and the lowest frequencies are "crowned" (2.1\%), "sealant or varnish" $(1 \%)$ and "white spot" $(0.2 \%)$.

Table 2 shows that from 127, 875 cases, $56.46 \%$ are women. The highest frequency of dental conditions of teeth 16 in men and women were "filled and not decay" followed by "missing by caries" and "decay". The $\chi^{2}$ test was highly significant $(\mathrm{p}<0.0001)$ (Table 2$)$, which means that the condition of the tooth is associated with the patient gender. Specifically, the masculine gender showed the strongest association with the conditions "decay" and "missing by caries" (observed frequencies higher than expected), while women are associated with the conditions "filled and decay" and "crowned" (observed frequencies higher than expected).

Table 3 shows the results of frequencies, percentages and cumulative percentage of dental conditions studied in the teeth 14P (upper left first permanent molars). These indicators behaved in the same way as the teeth 3P. The $\chi^{2}$ test was highly significant $(\mathrm{p}<0.0001)$ (Table 4$)$, which means that the condition of the tooth is 
Table 1. Results of the estimated frequency, percentage of affected persons and accumulated percentage in the upper right first permanent molar (3P).

\begin{tabular}{ccccccccccc}
\hline $\begin{array}{c}\text { Dental } \\
\text { Conditions } \\
(3 P)\end{array}$ & Decay & $\begin{array}{c}\text { Filled and } \\
\text { Decay }\end{array}$ & White spot & $\begin{array}{c}\text { Sealant or } \\
\text { varnish }\end{array}$ & $\begin{array}{c}\text { Filled and } \\
\text { not Decay }\end{array}$ & Crowned & $\begin{array}{c}\text { Missing by } \\
\text { caries }\end{array}$ & $\begin{array}{c}\text { Missing by } \\
\text { other } \\
\text { reason }\end{array}$ & Unerupted Unexamined & Total \\
Frequency & 24,047 & 8038 & 242 & 1319 & 58,406 & 2735 & 19,661 & 31 & 8 & 13,481 \\
Percentage & 18.8 & 6.28 & 0.19 & 1.03 & 45.6 & 2.13 & 15.4 & 0.02 & 0.006 & 10.53 \\
\hline
\end{tabular}

Table 2. Results of association between dental conditions and gender in the upper right first permanent molar (3P).

\begin{tabular}{|c|c|c|c|c|c|c|c|c|c|c|c|}
\hline Dental Conditions (3p) & Decay & $\begin{array}{c}\text { Filled and } \\
\text { Decay }\end{array}$ & $\begin{array}{l}\text { White } \\
\text { spot }\end{array}$ & $\begin{array}{c}\text { Sealant } \\
\text { or } \\
\text { varnish }\end{array}$ & $\begin{array}{c}\text { Filled and not } \\
\text { Decay }\end{array}$ & Crowned & $\begin{array}{l}\text { Missing } \\
\text { by caries }\end{array}$ & $\begin{array}{l}\text { Missing } \\
\text { by other } \\
\text { reason }\end{array}$ & Unerupted & Unexamined & Total \\
\hline \multicolumn{12}{|c|}{ Gender } \\
\hline Woman & 11,578 & 4779 & 127 & 729 & 34,767 & 1708 & 10,981 & 22 & 5 & 7510 & 72,206 \\
\hline Men & 12,460 & 3253 & 115 & 589 & 23,581 & 1022 & 8674 & 9 & 3 & 5963 & 55,669 \\
\hline Total & 24,038 & 8032 & 242 & 1318 & 58,348 & 2730 & 19,655 & 31 & 8 & 13473 & 127,875 \\
\hline
\end{tabular}

$\mathrm{X}^{2}=986$, 889; 9 gl; $\mathrm{p}<0.0001$. Note: 93 cases lost by lack of information on the gender of the subject under review.

Table 3. Results of the estimated frequency, percentage of affected persons and accumulated percentage in the upper left first permanent molar (14P).

\begin{tabular}{|c|c|c|c|c|c|c|c|c|c|c|c|}
\hline $\begin{array}{c}\text { Dental } \\
\text { Conditions } \\
(14 \mathrm{P})\end{array}$ & Decay & $\begin{array}{c}\text { Filled and } \\
\text { Decay }\end{array}$ & White spot & $\begin{array}{l}\text { Sealant or } \\
\text { varnish }\end{array}$ & $\begin{array}{l}\text { Filled and } \\
\text { not Decay }\end{array}$ & Crowned & $\begin{array}{c}\text { Missing by } \\
\text { caries }\end{array}$ & $\begin{array}{c}\text { Missing by } \\
\text { other } \\
\text { reason }\end{array}$ & Unerupted & Unexamined & Total \\
\hline Frequency & 24,445 & 8388 & 361 & 2257 & 62,187 & 2779 & 19,486 & 34 & 10 & 13,286 & 133,243 \\
\hline Percentage & 18.3 & 6.20 & 0.27 & 1.69 & 46.7 & 2.09 & 14.6 & 0.02 & 0.007 & 9.97 & \\
\hline
\end{tabular}

Table 4. Results of association between dental conditions and gender in the upper left permanent molar (14P).

\begin{tabular}{|c|c|c|c|c|c|c|c|c|c|c|c|}
\hline $\begin{array}{l}\text { Dental Conditions } \\
\qquad(14 p)\end{array}$ & Decay & $\begin{array}{l}\text { Filled and } \\
\text { Decay }\end{array}$ & $\begin{array}{l}\text { White } \\
\text { spot }\end{array}$ & $\begin{array}{c}\text { Sealant } \\
\text { or } \\
\text { varnish }\end{array}$ & $\begin{array}{l}\text { Filled and not } \\
\text { Decay }\end{array}$ & Crowned & $\begin{array}{l}\text { Missing } \\
\text { by caries }\end{array}$ & $\begin{array}{l}\text { Missing } \\
\text { by other } \\
\text { reason }\end{array}$ & Unerupted & Unexamined & Total \\
\hline \multicolumn{12}{|c|}{ Gender } \\
\hline Woman & 11,919 & 5061 & 199 & 1207 & 36,952 & 1770 & 10843 & 22 & 5 & 7412 & 75,390 \\
\hline Men & 12,526 & 3319 & 162 & 1048 & 25,175 & 1008 & 8632 & 12 & 5 & 5869 & 57,756 \\
\hline Total & 24,445 & 8380 & 361 & 2255 & 62,127 & 2778 & 19475 & 34 & 10 & 13,281 & 133,146 \\
\hline
\end{tabular}

$X^{2}=948$, 086; 9 gl; $p<0.0001$ Note: 97 cases lost by lack of information on the gender of the subject under review.

associated with the gender. Specifically, the male gender showed the strongest association to "decay" and "missing by caries", while the female gender is associated with "filled and decay", "filled and not decay" and "crowned".

Table 5 shows the results of frequencies, percentages and cumulative percentage of dental conditions studied in the teeth 19P (lower right first permanent molars). The highest frequency is "filled and not decay" (38, 9\%) as the same in teeth 14P, followed by "missing by caries" (20.8\%), "decay" (16.3\%), "filled and decay" (6.3\%), "sealant or varnish" $(0.8 \%)$ and "white spot" $(0.2 \%)$. The $\chi^{2}$ test was highly significant $(\mathrm{p}<0.001)$ (Table 6$)$, which means that the condition of the tooth is associated with the gender. Specifically, the male gender showed the strongest association to "decay" and "white spot", while the female gender is associated with the condition of "filled and decay", "filled and not decay", “crowned", and "missing by caries".

Table 7 shows the results of frequencies, percentages and cumulative percentage of dental conditions studied in the teeth 30P (lower left first permanent molars). These indicators behave in the same way as in the teeth 19P. The $\chi^{2}$ test was highly significant $(\mathrm{p}<0.0001)$ (Table 8$)$, which means that the condition of the tooth 
Table 5. Results of the estimated frequency and percentage of affected persons in the lower right first permanent molar (19P).

\begin{tabular}{ccccccccccccc}
\hline $\begin{array}{c}\text { Dental } \\
\begin{array}{c}\text { Conditions } \\
\text { (19P) }\end{array}\end{array}$ & Decay & $\begin{array}{c}\text { Filled and } \\
\text { Decay }\end{array}$ & White spot & $\begin{array}{c}\text { Sealant or } \\
\text { varnish }\end{array}$ & $\begin{array}{c}\text { Filled and } \\
\text { not Decay }\end{array}$ & Crowned & $\begin{array}{c}\text { Missing by } \\
\text { caries }\end{array}$ & $\begin{array}{c}\text { Missing by } \\
\text { other } \\
\text { reason }\end{array}$ & Unerupted Unexamined & Total \\
\hline Frequency & 21,401 & 8277 & 220 & 1059 & 51,023 & 2815 & 27245 & 34 & 16 & 18,988 & 131,078 \\
Percentage & 6.3 & 6.31 & 0.17 & 0.81 & 38.9 & 2.15 & 20.78 & 0.03 & 0.01 & 14.49 & \\
\hline
\end{tabular}

Table 6. Results of association between dental conditions and gender in the lower right first permanent molar (19P).

\begin{tabular}{ccccccccccccc}
\hline $\begin{array}{c}\text { Dental } \\
\text { Conditions } \\
(19 p)\end{array}$ & Decay & $\begin{array}{c}\text { Filled and } \\
\text { Decay }\end{array}$ & $\begin{array}{c}\text { White } \\
\text { spot }\end{array}$ & $\begin{array}{c}\text { Sealant or } \\
\text { varnish }\end{array}$ & $\begin{array}{c}\text { Filled and not } \\
\text { Decay }\end{array}$ & \multicolumn{2}{c}{$\begin{array}{c}\text { Missing by } \\
\text { caries }\end{array}$} & $\begin{array}{c}\text { Missing by } \\
\text { other reason }\end{array}$ & UneruptedUnexamined Total \\
\hline & & \multicolumn{7}{c}{ Gender } \\
\hline Woman & 9941 & 4704 & 110 & 644 & 29,755 & 1705 & 15,877 & 22 & 9 & 11,122 & 73,889 \\
Men & 11,452 & 3569 & 110 & 414 & 21,219 & 1107 & 11,356 & 12 & 7 & 7856 & 57,102 \\
Total & 21,393 & 8273 & 220 & 1058 & 50,974 & 2812 & 27,233 & 34 & 16 & 18,978 & 130,991 \\
\hline
\end{tabular}

$\mathrm{X}^{2}=1050,757 ; 9 \mathrm{gl} ; \mathrm{p}<0.001$ Note: 87 cases lost by lack of information on the gender of subject examined.

Table 7. Results of the estimated frequency and percentage of affected persons in the lower left first permanent molar (30P).

\begin{tabular}{ccccccccccccc}
\hline $\begin{array}{c}\text { Dental } \\
\text { Conditions } \\
\text { (30P) }\end{array}$ & Decay & \multicolumn{2}{c}{$\begin{array}{c}\text { Filled and } \\
\text { Decay }\end{array}$} & White spot $\begin{array}{c}\text { Sealant or } \\
\text { varnish }\end{array}$ & $\begin{array}{c}\text { Filled and } \\
\text { not Decay }\end{array}$ & Crowned & $\begin{array}{c}\text { Missing by } \\
\text { caries }\end{array}$ & $\begin{array}{c}\text { Missing by } \\
\text { other } \\
\text { reason }\end{array}$ & Unerupted Unexamined & Total \\
\hline Frequency & 21,483 & 8260 & 199 & 1049 & 51,827 & 2776 & 27,399 & 39 & 11 & 19,224 & 132,267 \\
Percentage & 16,2 & 6.24 & 0.15 & 0,79 & 39,18 & 2.1 & 20,7 & 0.03 & 0.008 & 14.53 & \\
\hline
\end{tabular}

Table 8. Results of association between dental conditions and gender in the lower left first permanent molar (30P).

\begin{tabular}{|c|c|c|c|c|c|c|c|c|c|c|c|}
\hline $\begin{array}{l}\text { Dental } \\
\text { Conditions } \\
\text { (30p) }\end{array}$ & Decay & $\begin{array}{l}\text { Filled and } \\
\text { Decay }\end{array}$ & $\begin{array}{l}\text { White } \\
\text { spot }\end{array}$ & $\begin{array}{l}\text { Sealant or } \\
\text { varnish }\end{array}$ & $\begin{array}{c}\text { Filled and no } \\
\text { Decay }\end{array}$ & ${ }^{t}$ Crowned & $\begin{array}{l}\text { Missing by } \\
\text { caries }\end{array}$ & $\begin{array}{l}\text { Missing by other } \\
\text { reason }\end{array}$ & ${ }^{\mathrm{r}}$ Unerupted & AUnexamines & ed Total \\
\hline \multicolumn{12}{|c|}{ Gender } \\
\hline Woman & 9966 & 4835 & 91 & 596 & 30,213 & 1697 & 15,855 & 26 & 8 & 11,201 & 74,488 \\
\hline Men & 11,51 & 3422 & 108 & 451 & 21,559 & 1075 & 11,531 & 13 & 3 & 8011 & 57,686 \\
\hline Total & 21,47 & 8257 & 199 & 1047 & 51,772 & 2772 & 27,386 & 39 & 11 & 19,212 & 132,174 \\
\hline
\end{tabular}

$\mathrm{X}^{2}=1061,167 ; 9 \mathrm{gl} ; \mathrm{p}<0.0001$ Note: 93 cases lost by lack of information on the gender of subject examined.

is associated with gender. Specifically, the male gender showed the strongest association to "decay" and "white spot", while the female is associated with the condition of "filled and decay", "filled and not decay", "crowned", "missing by caries" and "missing by other reason".

\section{Discussion}

This national multicenter study represents a diagnostic reality of oral health status, that establish treatment needs for the permanent first molar, in a large sample $(n=132,174)$ of the adult population who seek dental treatment in Chile. As a limitation, another network of public or private dental services is not considered. The DFMT index has the significance of being the most used index in epidemiological studies, but does not consider other conditions that may be present and should give more detail to the current state and history of tooth caries, such as "filled and decay "missing by caries", and "missing by another reason". The study results reveal a high presence of healthy filled molars (45.6\%), molars with carious lesions (18.8\%) and molars missing by caries (15.4\%). Specifically, this study demonstrates that gender is associated with the condition of the first molars in women differently than men. The finding of an independent association of gender was "healthy filled" condition. The results of this study are consistent with previous national studies, the National Health Interview Survey 
(NHIS) conducted in 2003 by the Ministry of Health, Government of Chile [5], which significantly demonstrates that men have more caveated caries lesions (decay) than women $(n=3308$, mean 2.97 vs 2.08 injuries respectively) and higher caries rate (69.7 vs 63.0), also showed that the age group most affected with caries was between 25 to 44 years old, meanwhile this study showed significant differences between men and woman, where the condition with highest rate in men was "decay", while in women was "filled and decayed", is also consistent the rate of caries lesions found in this study with outcomes of NHIS, represented in "filled and decay" and "decay” both reach $64.4 \%$ versus $66.0 \%$ respectively.

In light of the results obtained and given that the presence of caries lesions have the greatest impact on quality of life related to oral health, according to studies in India [16] $(\mathrm{n}=1200)$, issues that require attention are raised in oral health of adults referred to damage by caries, e.g. the need for preventive measures and minimally invasive dental treatment for primary caries lesions in men and caries lesions related to restoration in women, the need for prosthetic replacement of missing teeth both in women and men, and greater emphasis on the need for prevention and support therapy in oral health.

\section{Conclusion}

The gender is associated with oral health status in adults $(\mathrm{p}<0.05)$. The conditions of the permanent first molars with higher association in women were "filled and decay" and "missing by caries", in men were "decay" and "missing by caries". Due to the limitations of the present study, new multicenter studies are suggested to cover the whole dentition in adults, both in private and public network, in order to understand the damage in a broad context and estimate the real needs of treatment in adults.

\section{Acknowledgements}

Thanks to Marcelo Fernández, DDS for English grammar revision.

\section{References}

[1] Angel, P., Fresno, M.C., Cisternas, P., Lagos, M. and Moncada, G. (2010) Prevalence of Caries, Teeth Loss and Treatment Needs in Adult Mapuche-Huilliche Population in Isla Huapi. Revista Clínica de Periodoncia, Implantología y Rehabilitación Oral, 3, 69-72. http://dx.doi.org/10.1016/S0718-5391(10)70044-6

[2] Rojas, R. and Camus, M. (2001) Epidemiologic Study of Dental Caries in Children Using the dmft and DMFT Indexes of the Commune of Río Hurtado, IV Region. Revista Dental de Chile, 92, 17-22.

[3] Soto, L., Tapia, R., Jara, G., Rodríguez, G. and Urbina, T. (2007) National Assessment of Oral Health of Adolescents 12 Years and Assess the Degree of Compliance with the Health Oral Health Objectives 2000-2010. Chile 2007. http://web.minsal.cl/portal/url/item/7f2e0f67ebbc1bc0e04001011e016f58.pdf

[4] Ministry of Health, Government of Chile. http://web.minsal.cl/portal/url/item/9c81093d17385cafe04001011e017763.pdf

[5] Chilean Ministry of Health (Ministry of Health), National Health Survey 2003. http://web.minsal.cl/portal/url/item/9c81093d17385cafe04001011e017763.pdf

[6] Lamas, M. (2010) Has Dental Caries Prevalence Some Connection with Caries Index Values in Adults? Caries Research, 44, 81-4. http://dx.doi.org/10.1159/000279327

[7] Nguyen, T., Witter, D.J., Bronkhorst, E.M., Troung, N.B. and Creugers, N.H.J. (2010) Oral Health Status of Adults in Southern Vietnam-A Cross Sectional Epidemiological Study. BMC Oral Health, 10, 2. http://www.biomedcentral.com/1472-6831/10/2 http://dx.doi.org/10.1186/1472-6831-10-2

[8] Damyanov, N., Witter, D.J., Bronkhorst, E.M. and Creugers, N.H.J. (2012) Dental Status and Associated Factors in a Dentate Adult Population in Bulgaria: A Cross-Sectional Survey. International Dental Journal, 17, 2139-2150.

[9] Zhang, Q., Witter, D.J., Bronkhorst, E.M. and Creugers, N.H.J. (2011) Dental and Prosthodontic Status an over 40 Year-Old Population in Shandong Province, China. BMC Public Health, 11, 420. http://dx.doi.org/10.1186/1471-2458-11-420

[10] Sarita, P.T., Witter, D.J., Kreulen, C.M., Matee, M.I., van’t Hof, M.A. and Creugers, N.H. (2004) Decayed/Missing/Filled Teeth and Shortened Dental Arches in Tanzanian Adults. The International Journal of Prosthodontics, 17, 224-230.

[11] Brennan, D.S., Spencer, A.J. and Roberts-Thomson, K.F. (2007) Caries Experience among 45-54 Year Olds in Adelaide, South Australia. Australian Dental Journal, 52, 122-127. http://dx.doi.org/10.1186/1471-2458-11-420 
[12] Rihs, L., Silva, D. and Sousa, M. (2009) Dental Caries and Tooth Loss in Adults in a Brazilian Southeastern State. Journal of Applied Oral Science, 17, 392-396. http://dx.doi.org/10.1590/S1678-77572009000500008

[13] Nakatsuka, Y., Yamashita, S., Nimura, H., Mizoue, S., Tsuchiya, S. and Hashii, K. (2010) Location of Main Occluding Areas and Masticatory Ability in Patients with Reduced Occlusal Support. Australian Dental Journal, 55, 45-50. http://dx.doi.org/10.1111/j.1834-7819.2009.01174.x

[14] Díaz-Narváez, V.P. (2009) Scientific Research Methodology and Biostatistics for Professionals and Students of Health Sciences. RIL Editors, Santiago, Chile.

[15] Vargas, V., Krause, C. and Díaz-Narváez, V.P. (2015) Estimated Average Value of the COPD Indicator. Chile, 2012. Salud Uninorte, 31, 276-283. http://dx.doi.org/10.14482/sun.31.2.5551

[16] Sanadhya, S., Aapaliya, P., Jain, S., Sharma, N., Choudhary, G. and Dobaria, N. (2015) Assessment and Comparison of Clinical Dental Status and Its Impact on Oral Health-Related Quality of Life among Rural and Urban Adults of Udaipur, India: A Cross-Sectional Study. Journal of Basic and Clinical Pharmacy, 6, 50-58. http://dx.doi.org/10.4103/0976-0105.152091 